Prepared in cooperation with the Indiana Office of Community and Rural Affairs

\title{
Flood-Inundation Maps for the Wabash and Eel Rivers at Logansport, Indiana
}
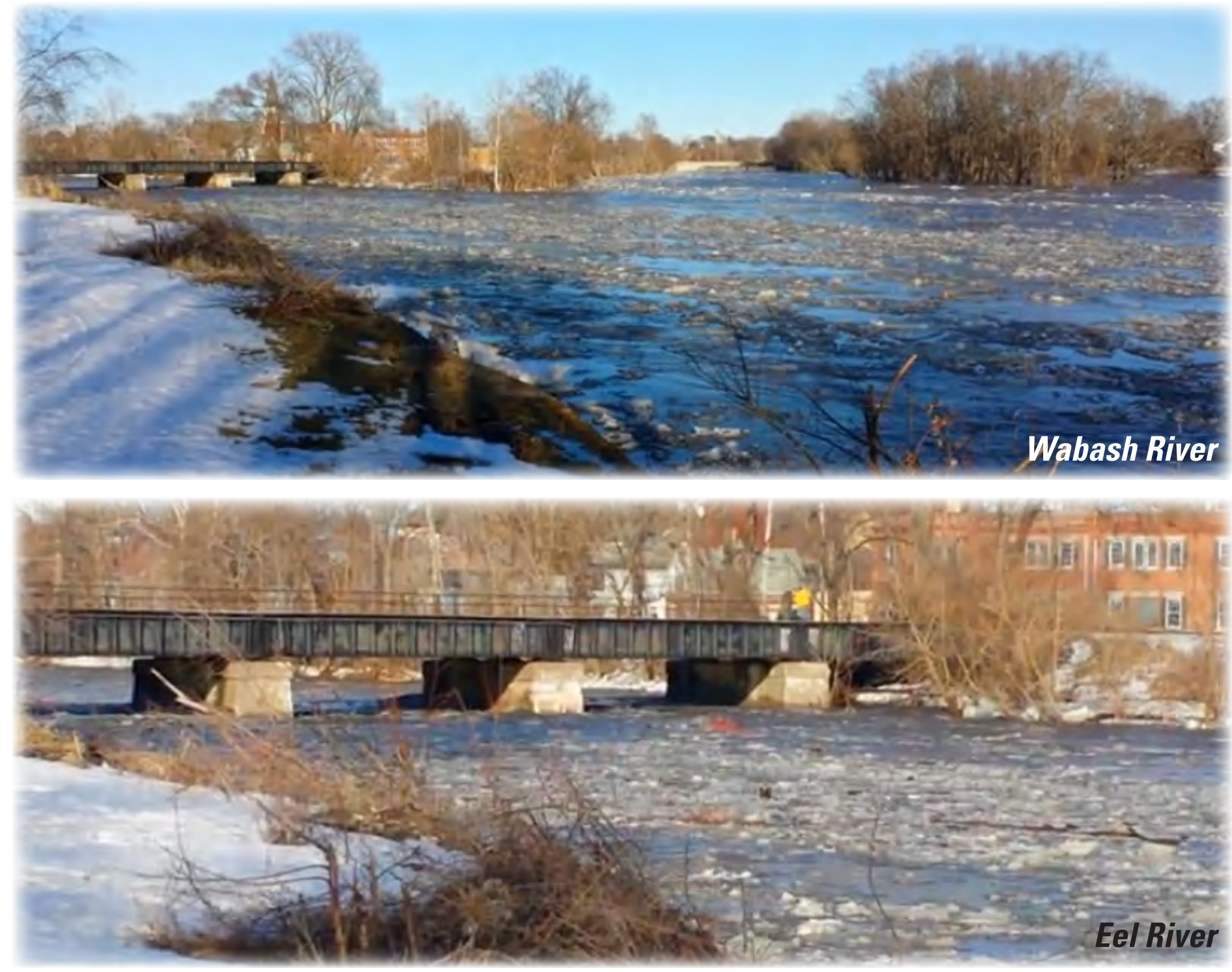

Pamphlet to accompany

Scientific Investigations Map 3293 


\section{Cover:}

Upper photo: Wabash River downstream of the confluence with Eel River, Logansport, Indiana.

Lower photo: Eel River upstream of the confluence with the Wabash River, Logansport, Indiana. Photographs courtesy of Michael McKinney, February 2014. 


\section{Flood-Inundation Maps for the Wabash and Eel Rivers at Logansport, Indiana}

By Kathleen K. Fowler

Prepared in cooperation with the Indiana Office of Community and Rural Affairs

Pamphlet to accompany

Scientific Investigations Map 2014-3293 


\title{
U.S. Department of the Interior SALLY JEWELL, Secretary
}

\section{U.S. Geological Survey Suzette M. Kimball, Acting Director}

\author{
U.S. Geological Survey, Reston, Virginia: 2014
}

For more information on the USGS - the Federal source for science about the Earth, its natural and living resources, natural hazards, and the environment, visit http://www.usgs.gov or call 1-888-ASK-USGS.

For an overview of USGS information products, including maps, imagery, and publications, visit http://www.usgs.gov/pubprod

To order this and other USGS information products, visit http://store.usgs.gov

Any use of trade, firm, or product names is for descriptive purposes only and does not imply endorsement by the U.S. Government.

Although this information product, for the most part, is in the public domain, it also may contain copyrighted materials as noted in the text. Permission to reproduce copyrighted items must be secured from the copyright owner.

Suggested citation:

Fowler, K.K., 2014, Flood-inundation maps for the Wabash and Eel Rivers at Logansport, Indiana: U.S. Geological Survey Scientific Investigations Map 3293, 9 sheets, 12-p. pamphlet, http://dx.doi.org/10.3133/sim3293.

http://dx.doi.org/10.3133/sim3293

ISSN 2329-132X (online) 


\section{Contents}

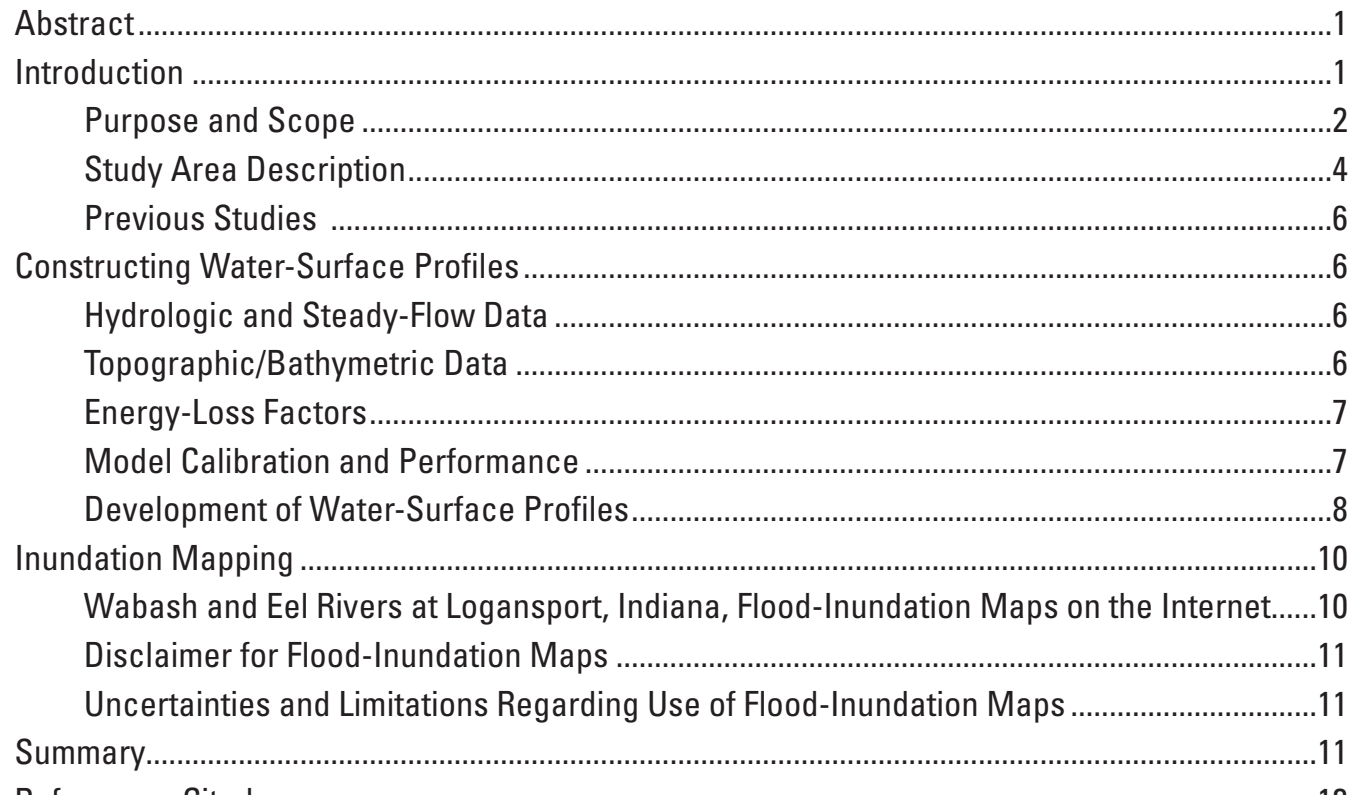

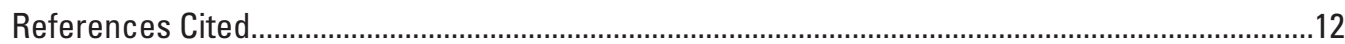

\section{Map Sheets}

[Map sheets and additional materials are available online at http://pubs.usgs.gov/sim/3293/.]

1-5. Estimated flood-inundation maps for the Wabash River at Logansport, Indiana, referenced to USGS streamgage 03329000 for stream stages of-

1. $\quad 11.00$ feet and an elevation of 583.89 feet (map sheet 1 of 9 )

2. $\quad 12.00$ feet and an elevation of 584.89 feet (map sheet 3 of 9 )

3. $\quad 13.00$ feet and an elevation of 585.89 feet (map sheet 5 of 9 )

4. $\quad 14.00$ feet and an elevation of 586.89 feet (map sheet 6 of 9 )

5. $\quad 15.00$ feet and an elevation of 587.89 feet (map sheet 8 of 9 )

6-9. Estimated flood-inundation maps for the Eel River near Logansport, Indiana, at USGS streamgage 03328500 for stream stages of-

6. $\quad 10.00$ feet and an elevation of 631.11 feet (map sheet 2 of 9 )

7. $\quad 11.00$ feet and an elevation of 632.11 feet (map sheet 4 of 9 )

8. 12.00 feet and an elevation of 633.11 feet (map sheet 7 of 9 )

9. $\quad 13.00$ feet and an elevation of 634.11 feet (map sheet 9 of 9 )

\section{Figures}

1. Location of study reach for the Wabash and Eel Rivers and location of USGS

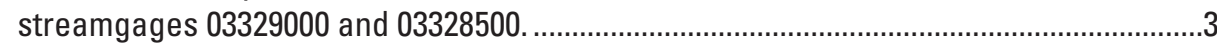

2. Drainage basins of the Wabash and Eel Rivers upstream of the study area.....................5

3. Regression plot and equation used to predict discharge at the Eel River.........................9

4. Regression plot and equation used to predict discharge at the Wabash River...............10 


\section{Tables}

1. USGS streamgage and miscellaneous site information for the Wabash and Eel Rivers, Logansport, Indiana

2. 1.0 percent annual exceedance probability peak-discharge estimates and drainage areas for selected locations on the Wabash and Eel Rivers ....

3. Comparison of water-surface elevations at USGS streamgage 03329000 , Wabash River at Logansport, Indiana, with water-surface elevations output from the hydraulic model.

4. Comparison of water-surface elevations at USGS streamgage 03328500, Eel River near Logansport, Indiana, with water-surface elevations output from the hydraulic model

5. Comparison of hydraulic-model output and surveyed high-water-mark elevations from the flood of July 7, 2003, for the Wabash River at Logansport, Indiana

6. Comparison of hydraulic-model output and surveyed high-water-mark elevations from the flood of January 10, 2008, for the Eel River near Logansport, Indiana.

7. Stages, water-surface elevations, and corresponding discharge estimates for U.S. Geological Survey streamgages 03329000 , Wabash River at Logansport, and 03328500, Eel River near Logansport, Indiana, for simulated water-surface profiles.

\section{Conversion Factors}

Inch/Pound to SI

\begin{tabular}{lcl}
\hline \multicolumn{1}{c}{ Multiply } & By & \multicolumn{1}{c}{ To obtain } \\
\hline foot $(\mathrm{ft})$ & Length & \\
mile $(\mathrm{mi})$ & 0.3048 & meter $(\mathrm{m})$ \\
& 1.609 & kilometer $(\mathrm{km})$ \\
\hline square mile $\left(\mathrm{mi}^{2}\right)$ & Area & \\
\hline & 2.590 & square kilometer $\left(\mathrm{km}^{2}\right)$ \\
\hline cubic foot per second $\left(\mathrm{ft}^{3} / \mathrm{s}\right)$ & Flow rate & \\
\hline & 0.02832 & cubic meter per second $\left(\mathrm{m}^{3} / \mathrm{s}\right)$ \\
\hline foot per mile $(\mathrm{ft} / \mathrm{mi})$ & Hydraulic gradient & \\
\hline
\end{tabular}

Vertical coordinate information is referenced to either (1) stage, the height above an arbitrary datum established at a streamgage, or (2) elevation, the height above North American Vertical Datum of 1988 (NAVD 88).

Horizontal coordinate information is referenced to the North American Datum of 1983 (NAD 83). 


\section{Acknowledgments}

The author wishes to thank the many local, State, and Federal agencies that have cooperated in the funding for the operation and maintenance of the gages used for this study, especially the U.S. Army Corps of Engineers-Louisville District and the Indiana Department of Natural Resources. Special thanks are given to Indiana Office of Community and Rural Affairs for their cooperation in this study and to the National Weather Service for their continued support to the USGS flood-inundation mapping initiative. 



\title{
Flood-Inundation Maps for the Wabash and Eel Rivers at Logansport, Indiana
}

\author{
By Kathleen K. Fowler
}

\begin{abstract}
Digital flood-inundation maps for an 8.3-mile reach of the Wabash River and a 7.6-mile reach of the Eel River at Logansport, Indiana (Ind.), were created by the U.S. Geological Survey (USGS) in cooperation with the Indiana Office of Community and Rural Affairs. The inundation maps, which can be accessed through the USGS Flood Inundation Mapping Science Web site at http://water.usgs.gov/osw/ flood_inundation/, depict estimates of the areal extent and depth of flooding corresponding to selected water levels (stages) at USGS streamgage Wabash River at Logansport, Ind. (sta. no. 03329000) and USGS streamgage Eel River near Logansport, Ind. (sta. no. 03328500). Current conditions for estimating near-real-time areas of inundation using USGS streamgage information may be obtained on the Internet at http://waterdata.usgs.gov/. In addition, information has been provided to the National Weather Service (NWS) for incorporation into their Advanced Hydrologic Prediction Service (AHPS) flood warning system (http:/water.weather.gov/ahps/). The NWS forecasts flood hydrographs at many places that are often colocated with USGS streamgages. NWS-forecasted peak-stage information may be used in conjunction with the maps developed in this study to show predicted areas of flood inundation.

For this study, flood profiles were computed for the stream reaches by means of a one-dimensional step-backwater model developed by the U.S. Army Corps of Engineers. The hydraulic model was calibrated by using the most current stage-discharge relations at USGS streamgages 03329000 , Wabash River at Logansport, Ind., and 03328500, Eel River near Logansport, Ind. The calibrated hydraulic model was then used to determine five water-surface profiles for flood stages at 1-foot intervals referenced to the Wabash River streamgage datum, and four water-surface profiles for flood stages at 1-foot intervals referenced to the Eel River streamgage datum. The stages range from bankfull to approximately the highest stages that have occurred since 1967 when three flood control dams were built upstream of Logansport, Ind. The simulated water-surface profiles were then combined with a geographic information system (GIS) digital elevation model (DEM,
\end{abstract}

derived from Light Detection and Ranging [lidar] data having a 0.37-foot vertical accuracy and 3.9-foot horizontal resolution) in order to delineate the area flooded at each stage.

The availability of these maps, along with information available on the Internet regarding current stages from the USGS streamgages at Logansport, Ind., and forecasted stream stages from the NWS, provides emergency management personnel and residents with information that is critical for flood response activities such as evacuations and road closures, as well as for postflood recovery efforts.

\section{Introduction}

The city of Logansport, Indiana (Ind.) is a small urban community with an estimated population of 18,393 (U.S. Census Bureau, 2010). Logansport has experienced severe flooding numerous times, especially before 1967 when three flood control dams were built upstream of the city. Significant floods occurred in 1912, 1913, 1943, 1959, and 1985 (FEMA, 1979). Areas most affected by the flooding are along the Wabash and Eel Rivers, which flow through Logansport. Flood plains within and near Logansport are moderately developed and contain a mix of residential, commercial, and agricultural areas.

Prior to this study, Logansport officials relied on several information sources to make decisions on how to best alert the public and mitigate flood damages. One source of information is the Federal Emergency Management Agency (FEMA) Flood Insurance Study (FIS) for Cass County dated 1979 (FEMA, 1979). A second source is USGS streamgage 03329000 Wabash River at Logansport, Ind., and USGS streamgage 03328500 Eel River near Logansport, Ind. from which current and historical water levels (stage) can be obtained (USGS National Water Information System, http://waterdata.usgs. gov/). A third source is the National Weather Service's forecast of peak stage at USGS streamgage 03329000 Wabash River at Logansport, Ind., through their Advanced Hydrologic Prediction Service (AHPS) Web site (http:/water.weather.gov/ ahps/). Although USGS stream stage and NWS flood forecast 
information is particularly useful for residents in the immediate vicinity of a streamgage, it is of limited use to residents farther upstream or downstream because the water-surface elevation is not constant along the entire stream channel. Also, FEMA and State emergency management mitigation teams or property owners typically lack information related to how deep the water is at locations other than near USGS streamgage or NWS flood-forecast points.

\section{Purpose and Scope}

The purpose of this report is to describe the development of a series of estimated flood-inundation maps for the Wabash and Eel Rivers at Logansport, Ind. The maps and other flood information are available on the USGS Flood Inundation Mapping Science Web site (http://water.usgs.gov/ osw/flood_inundation/). Internet users can select estimated inundation maps that correspond to (1) current stages at the USGS streamgages, (2) the NWS forecasted peak stage for the Wabash River, or (3) other desired stream stages.

The scope of the study was limited to an 8.3-mile (mi) reach of the Wabash River beginning at an upstream location near Rock Island and continuing downstream to a location approximately $1.1 \mathrm{mi}$ downstream of US Highway 24/35, and a 7.6-mi reach of the Eel River beginning at a location approximately 0.25 mile upstream of County Road 150 North and extending downstream to the confluence with the Wabash River (fig. 1). Tasks specific to construction and display of the maps were (1) compilation of flow data from streamgage 03329000 and streamgage 03328500 (table 1), (2) collection of topographic data and geometric data (for structures/bridges) throughout the study reach, (3) estimation of energy-loss factors (roughness coefficients) in the stream channels and flood plains, (4) computation of water-surface profiles by use of the U.S. Army Corps of Engineers' HEC-RAS computer program (U.S. Army Corps of Engineers, 2010), (5) production of estimated flood-inundation maps at various stream stages by use of the U.S. Army Corps of Engineers' HEC-GeoRas computer program (U.S. Army Corps of Engineers, 2009) and a Geographic Information System (GIS), and (6) development of a Web interface that links to USGS real-time streamgage information and (or) NWS forecasted peak stage to facilitate the display of user-selected flood-inundation maps on the Internet.

Methods used are generally cited from previously published reports. If techniques varied significantly from previously documented methods due to local hydrologic conditions or available data, they are described in detail in this report. Nine inundation maps were produced for water levels referenced to the water-surface elevation (stage) at USGS streamgage 03329000 and USGS streamgage 03328500 , Wabash and Eel Rivers at Logansport, Ind., and range from approximately bankfull to more than a foot higher than the highest stage since 1967 on the Wabash River and the highest stage on the current stage-discharge rating table (number 23) for the Eel River

The period of record for the Wabash River gage dates from 1923. Between 1923 and 1967 Logansport experienced numerous floods that exceed those represented in this study. The most notable floods on the Wabash River at Logansport include: 86,600 cubic feet per second $\left(\mathrm{ft}^{3} / \mathrm{s}\right.$ ) (stage of $21.00 \mathrm{ft}$ ) in $1912,140,000 \mathrm{ft}^{3} / \mathrm{s}$ (stage of $25.30 \mathrm{ft}$ ) in 1913, and 89,800 $\mathrm{ft}^{3} / \mathrm{s}$ (stage of $21.32 \mathrm{ft}$ ) in 1943 (FEMA, 1979). Circa 1967, three dams were constructed upstream of Logansport by the U.S. Army Corps of Engineers to provide flood damage reduction along this stretch of the Wabash River. This system is composed of three dams: one on the main stream and two on major tributaries. Upstream from Logansport, the first of these dams is on the Mississinewa River near Peoria. The second dam is on the Salamonie River upstream from the Wabash River channel near Lagro. The third dam at Huntington Reservoir (or J.E. Roush Lake, as it is currently named) is on the main branch of the Wabash River (fig. 2). These reservoirs control approximately half of the drainage area above Logansport (FEMA, 1979). The stage on the Wabash River has not exceeded $15 \mathrm{ft}$ since the dams began their flood control function. Because the purpose of this study is to represent current conditions in the Logansport area, flood stages above $15 \mathrm{ft}$ were not modeled. The gage on the Eel River was established in 1943. This stream is affected by a low-head dam located approximately $1.2 \mathrm{mi}$ upstream of the confluence with the Wabash River. The Eel River has a fairly consistent range of peak stages. One flood on the Eel River in 1943 slightly exceeded the high water modeled in this study. That flood had a discharge of $89,800 \mathrm{ft}^{3} / \mathrm{s}$ (stage of $13.20 \mathrm{ft}$ ). Since 1967, the highest stage recorded was $12.68 \mathrm{ft}$ in 1985 . Because both the Wabash and the Eel were being modeled together, the same period of record (1967-2011) was used for both streams.

The interaction of the two streams is unusual in that the annual peak streamflows at a tributary river frequently occur before that of the main branch. Rivers with small drainage areas typically can be expected to peak more quickly after precipitation or snowmelt events than those with large drainage areas. However, the Wabash and Eel Rivers are an exception to this general principle. The regulation of the reservoirs upstream of the Wabash gage affects the timing of the peaks. The annual peak discharges of each river were compared to determine how often the peaks occurred on the same day or within 1 day of the other. The annual peak on the Wabash River occurred 1 day before the Eel River annual peak for 17 years of annual peak streamflow record (38 percent of the time) since 1967. The rivers had annual peaks on the same day 12 times since 1967 or 27 percent of the time. Because the two rivers peak within 1 day of the other more than half the time, the rivers were modeled to represent both rivers peaking on the same day. This scenario likely would result in the largest areas that would be inundated within the study reaches by either river in flood, and thus should be a useful "worstcase" scenario for emergency management operations. It also 


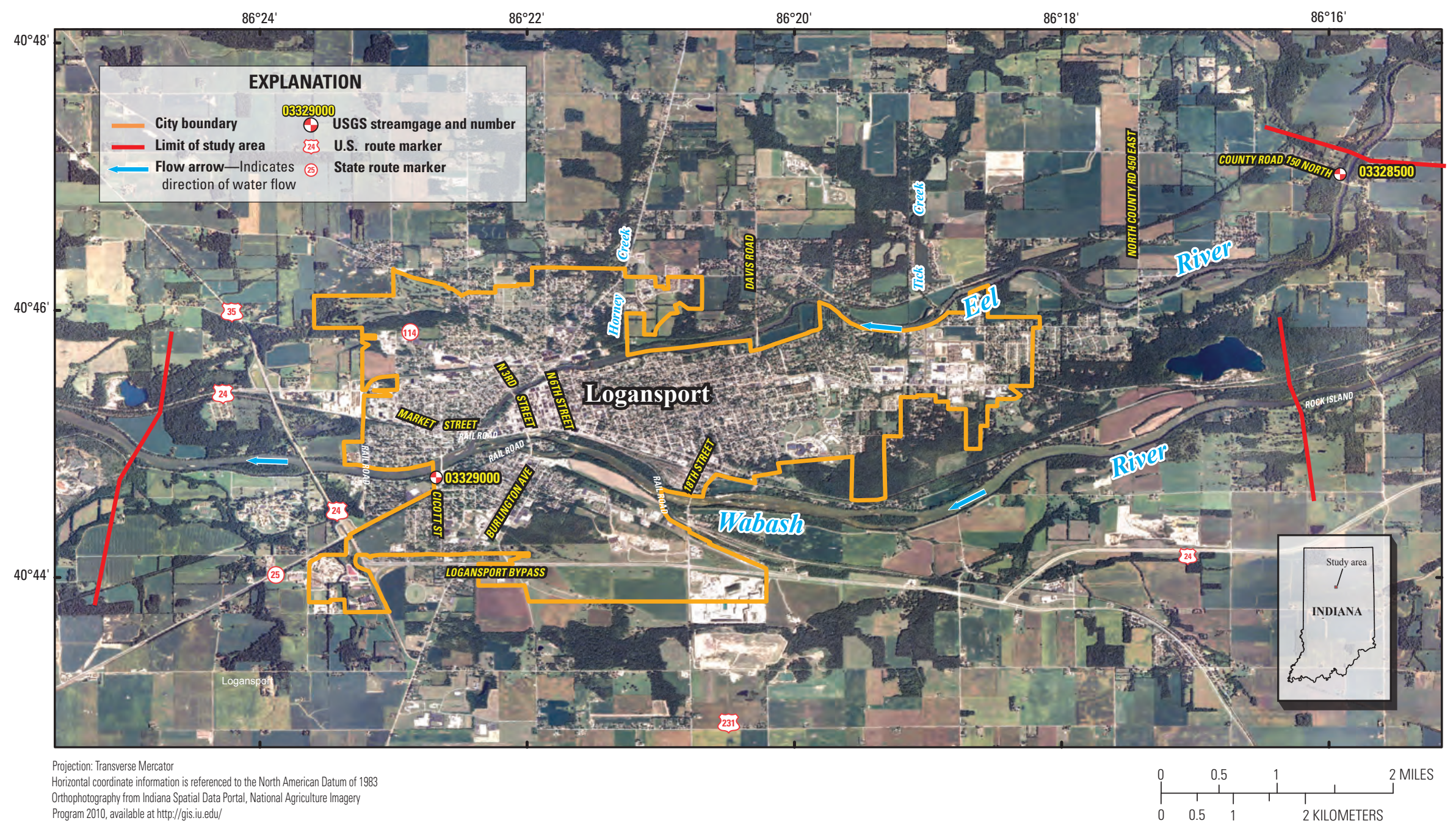

Figure 1. Location of study reach for the Wabash and Eel Rivers and location of USGS streamgages 03329000 (with National Weather Service forecast site LGNI3) and 03328500 . 
Table 1. U.S. Geological Survey streamgage and miscellaneous site information for the Wabash and Eel Rivers, Logansport, Indiana. [mi², square miles; NAD 83, North American Datum of 1983; NAVD 88, North American Vertical Datum of 1988; ft, feet]

\begin{tabular}{|c|c|c|c|c|c|c|c|c|}
\hline $\begin{array}{c}\text { Streamgage } \\
\text { name }\end{array}$ & $\begin{array}{c}\text { Streamgage } \\
\text { number }\end{array}$ & $\begin{array}{c}\text { Drainage } \\
\text { area } \\
\left(\mathrm{mi}^{2}\right)\end{array}$ & $\begin{array}{l}\text { Latitude } \\
\text { (NAD 83) }\end{array}$ & $\begin{array}{c}\text { Longitude } \\
\text { (NAD 83) }\end{array}$ & $\begin{array}{l}\text { Period of } \\
\text { record }\end{array}$ & $\begin{array}{l}\text { Datum of } \\
\text { gage } \\
\text { (NAVD 88) }\end{array}$ & $\begin{array}{l}\text { Maximum } \\
\text { recorded flood } \\
\text { elevation } \\
\text { (NAVD 88) and } \\
\text { date }\end{array}$ & $\begin{array}{l}\text { Maximum recorded } \\
\text { flood elevation } \\
\text { (NAVD 88) and date } \\
\text { since } 1967\end{array}$ \\
\hline $\begin{array}{l}\text { Wabash River at } \\
\text { Logansport, } \\
\text { Ind. }\end{array}$ & 03329000 & 3,779 & $40^{\circ} 44^{\prime} 47^{\prime \prime}$ & $86^{\circ} 22^{\prime} 39^{\prime \prime}$ & $\begin{array}{l}\text { May } 1923 \\
\text { to present }\end{array}$ & $572.89 \mathrm{ft}$ & $\begin{array}{l}598.19 \mathrm{ft} \text { on } \\
\text { March 26, } 1913 \\
\text { (corresponds to } \\
\text { a stage of } \\
25.30 \mathrm{ft})^{1}\end{array}$ & $\begin{array}{l}586.91 \mathrm{ft} \text { on } \\
\text { February } 24,1985 \\
\text { (corresponds to a } \\
\text { stage of } 14.02 \mathrm{ft} \text { ). }\end{array}$ \\
\hline $\begin{array}{l}\text { Eel River near } \\
\text { Logansport, } \\
\text { Ind. }\end{array}$ & 03328500 & 789 & $40^{\circ} 46^{\prime} 58^{\prime \prime}$ & $86^{\circ} 15^{\prime} 52^{\prime \prime}$ & $\begin{array}{l}\text { July } 1943 \\
\text { to present }\end{array}$ & $621.11 \mathrm{ft}$ & $\begin{array}{l}634.31 \mathrm{ft} \text { on } \\
\text { May } 18,1943 \\
\text { (corresponds to } \\
\text { a stage of } \\
13.20 \mathrm{ft} \text { ) }\end{array}$ & $\begin{array}{l}633.79 \mathrm{ft} \text { on } \\
\text { February } 24,1985 \\
\text { (corresponds to a } \\
\text { stage of } 12.68 \mathrm{ft} \text { ). }\end{array}$ \\
\hline
\end{tabular}

${ }^{1}$ From highwater mark

reflects reasonably well with the most significant floods that have occurred under current conditions. However, it is important to note that flows in the Eel River and flows in the Wabash River are the result of precipitation events that occur within their respective basins. Scenarios when peaks in the two basins do not coincide or are greater than 1 day apart are not reflected in this model.

\section{Study Area Description}

The Wabash and Eel Rivers near the city of Logansport are in north central Indiana at the northern edge of the Tipton Till Plain physiographic section of the Central Till Plain Region (Gray, 2000). The basin terrain is relatively uniform with low relief. The Wabash River drainage area is 2,946 square miles $\left(\mathrm{mi}^{2}\right)$ at the upstream end of the study reach, $3,779 \mathrm{mi}^{2}$ at USGS streamgage 03329000 , and $3,789 \mathrm{mi}^{2}$ at the downstream extent of the study reach. The headwaters of the Wabash River originate in Mercer County, Ohio, near the village of Fort Recovery, about 115 mi. upstream of Logansport, and the stream flows generally westward before entering the city limits (fig. 2). In Logansport, the river flows from east to west. One major tributary to the Wabash River, the Eel River, joins the main stem as it flows through the city. The Wabash River study reach has an average top-of-bank channel width of about $675 \mathrm{ft}$ and an average channel slope of 0.00049 ( $2.7 \mathrm{ft} / \mathrm{mi}$ ) (from USGS field survey, August 2012). The Eel River drainage area is $789 \mathrm{mi}^{2}$ at the USGS streamgage
03328500 near the upstream end of the study reach and 815 $\mathrm{mi}^{2}$ at the mouth. The headwaters of the Eel River originate in Allen County, about 92 mi upstream of Logansport and the stream flows generally southeastward before entering the city. The Eel River reach has an average top-of-bank channel width of about $271 \mathrm{ft}$ and an average channel slope of $.0012(6.2 \mathrm{ft} /$ mi) (from USGS field survey, August 2012).

The Wabash River, within the study reach, has four major road crossings and four railroad crossings within the channel or the adjacent flood plain. The main channel of the Eel River has six major road crossings and one railroad crossing. The entire study reach, including both rivers, is approximately 15.9 mi long. Development continues in the study basin despite a recent population decline of 6.6 percent (from 19,684 to 18,396) between 2000 and 2010 (U.S. Census Bureau, 2010).

\section{Previous Studies}

The current FIS for Cass County (FEMA, 1979) was completed by Mid-States Engineering Co. Inc. and Johnson and Anderson, Inc. A redelineation of the effective flood hazard information was performed by Christopher B. Burke, Ltd. in 2007. An estimate of the peak discharge for the 1.0 percent annual exceedance probability flood for selected locations on the Wabash and Eel Rivers was obtained from the Cass County FIS (FEMA, 1979) and are listed in table 2. 


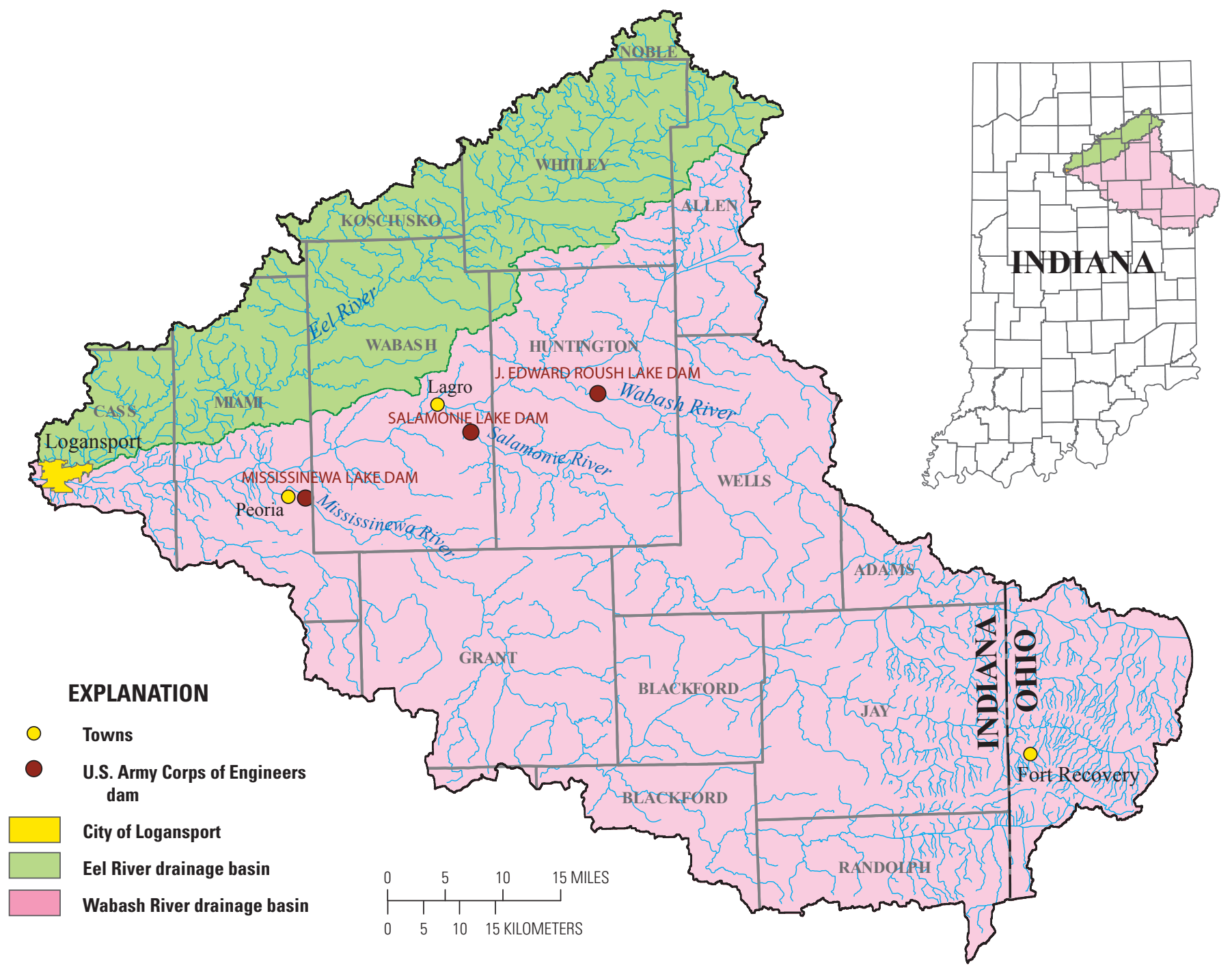

Figure 2. Drainage basins of the Wabash and Eel Rivers upstream of the study area.

Table 2. 1.0 percent annual exceedance probability peak-discharge estimates and drainage areas for selected locations on the Wabash and Eel Rivers (Cass County FIS (Federal Emergency Management Agency, 1979)).

$\left[\mathrm{mi}^{2}\right.$, square miles; $\mathrm{ft}^{3} / \mathrm{s}$, cubic feet per second]

\begin{tabular}{lcc}
\hline \multicolumn{1}{c}{ Location } & $\begin{array}{c}\text { Discharge estimate } \\
\left(\mathbf{f t}^{3} \mathbf{s}\right)\end{array}$ & $\begin{array}{c}\text { Drainage area } \\
\left(\mathbf{m i}^{2} \mathbf{)}\right.\end{array}$ \\
\hline Wabash River upstream of confluence with Eel River & 40,000 & 2,964 \\
Wabash River downstream of confluence with Eel River & 65,000 & 3,779 \\
Eel River at East County Road 150 North, USGS & 17,800 & 789 \\
$\quad$ streamgage 03328500 & & \\
Eel River at mouth & 18,500 & 815 \\
\hline
\end{tabular}




\section{Constructing Water-Surface Profiles}

The water-surface profiles used to produce the nine flood-inundation maps in this study were simulated by using HEC-RAS, version 4.1.0 (U.S. Army Corps of Engineers, 2010). HEC-RAS is a one-dimensional step-backwater model for simulation of water-surface profiles with gradually varied, steady-state (or unsteady-state) flow computation options. The HEC-RAS analysis for this study was done using the steadystate flow computation option.

\section{Hydrologic and Steady-Flow Data}

The study-area hydrologic network consists of two streamgages (fig. 1; table 1). The Wabash River gage has been in operation since 1923. The Eel River gage began operating in 1943. Water level (stage) is measured continuously at both of the sites, and continuous records of streamflow are computed at both of the sites. The USGS streamgages are $6.4 \mathrm{mi}$ apart in over-land distance. Water-surface elevations corresponding to the stages are referenced to North American Vertical Datum of 1988 (NAVD 88) in this report. The USGS gages are equipped with satellite radio transmitters that allow data to be transmitted routinely on the Internet within an hour of collection. Flow data for the Wabash gage can be accessed at http://waterdata. usgs.gov/in/nwis/uv/? site_no $=03329000 \&$ PARAmeter $c d=00065,00060,00010$. Flow data for the Eel River gage can be accessed at http://waterdata.usgs.gov/in/nwis/ $u v / ?$ site_no $=03328500 \&$ PARAmeter_cd $=00065,00060,00010$.

The steady-flow data necessary for the hydraulic model consisted of flow regime, boundary conditions (normal depth), and peak-discharge information. The steady-flow data were obtained from field measurements of streamflow at USGS streamgage 03329000, Wabash River at Logansport, Ind. and at USGS streamgage 03328500 , Eel River near Logansport, Ind. All computations used discharge values with known stages from actual streamflow measurements or the stagedischarge relations at the gage.

\section{Topographic/Bathymetric Data}

Seventy-two channel cross sections were developed from USGS field surveys that were conducted in August 2012 (38 on the Eel River and 34 on the Wabash River); these cross sections provide detailed channel-elevation data below the water surface and were collected by using hydroacoustic instrumentation to measure depth and Differential Global Positioning System (DGPS) instrumentation to determine horizontal position. Lidar data were used to obtain digital elevation data for the portions of the cross sections that were above the water surface at the time of the surveys. The lidar data were collected and postprocessed in 2010 by Aero-Metric, Inc., Sheboygan, Wisconsin. The lidar data have horizontal accuracy of $1.02 \mathrm{ft}$ with horizontal resolution of $3.9 \mathrm{ft}$ and vertical accuracy of $0.37 \mathrm{ft}$ at a 95 -percent confidence level. Although a finer resolution of the DEM was possible given the accuracy of the lidar data, the final DEM had a grid-cell size of $10 \mathrm{ft}$ by $10 \mathrm{ft}$ in order to decrease the GIS processing time. This resulted in a vertical accuracy of plus or minus $1 \mathrm{ft}$.

Various manmade drainage structures (bridges, culverts, roadway embankments, levees, and dams) in and along the Wabash and Eel Rivers affect or have the potential to affect water-surface elevations during floods along the stream. To properly account for these features in the model, structural dimensions for 15 bridges and 1 instream structure, a low-head dam, were measured and surveyed in the field concurrently with the stream channel surveys. A detailed description of the methods used to acquire and process the topographic and bathymetric data can be found in Bales and others (2007).

\section{Energy-Loss Factors}

Field observations and high-resolution aerial photographs obtained from the Indiana Spatial Data Portal, National Agricultural Imagery Program 2010 (http://gis.iu.edu/) were used to select initial (precalibration) channel and flood-plain friction coefficients. These friction coefficients, commonly called Manning's roughness coefficients or Manning's $n$ values, account for energy (friction) loss in the model (Arcement and Schneider, 1989). The final Manning's $n$ values used for the Wabash River ranged from 0.030 to 0.035 for the main channel and 0.060 to 0.090 for the overbank areas modeled in this analysis. The final Manning's $n$ values used for the Eel River were 0.035 for the main channel and 0.070 to 0.090 for the overbank areas modeled in this analysis.

\section{Model Calibration and Performance}

The hydraulic models were calibrated to the most current stage-discharge relation (USGS rating no. 38, June 27, 2012) at USGS streamgage 03329000, Wabash River at Logansport, Ind., and (USGS rating no. 23, January 9, 2003) at USGS streamgage 03328500, Eel River near Logansport, Ind. Calibration of the models was also aided by comparison to high-water marks from the flood of July 7, 2003, on the Wabash River and the flood of January 10, 2008, on the Eel River. The estimated peak discharge for the 2003 flood on the Wabash River was $37,100 \mathrm{ft}^{3} / \mathrm{s}$ at an estimated stage of about $13.60 \mathrm{ft}$ at the gage. The estimated peak discharge for the 2008 flood on the Eel River was 13,300 ft $3 / \mathrm{s}$ at an estimated stage of about $11.26 \mathrm{ft}$ at the gage. Model calibration was accomplished by adjusting Manning's $n$ values and, in some cases, changing the channel cross section or slope until the results of the hydraulic computations closely agreed with the known flood discharge and stage values. The two models were run separately using essentially the same geometry file. The differences were the values in the steady flow data table. Differences between measured and simulated water levels at USGS gaging station 03329000 were equal to or less than 0.10 
$\mathrm{ft}$ for five profiles (table 3). Differences between measured and simulated water levels at USGS gaging station 03328500 were equal to or less than $0.16 \mathrm{ft}$ for the four profiles (table 4). Differences between measured and simulated water levels for models calibrated to high-water marks from the flood of July 7, 2003, on the Wabash River in the study reach were less than

Table 3. Comparison of water-surface elevations at U.S. Geological Survey streamgage 03329000, Wabash River at Logansport, Indiana, with water-surface elevations output from the hydraulic model.

[ft, feet; NAVD 88, North American Vertical Datum of 1988]

\begin{tabular}{cccc}
\hline $\begin{array}{c}\text { Stage } \\
\text { (ft) }\end{array}$ & $\begin{array}{c}\text { Estimated } \\
\text { water-surface } \\
\text { elevation from } \\
\text { stage-discharge rating } \\
\text { (ft, NAVD 88) }\end{array}$ & $\begin{array}{c}\text { Modeled } \\
\text { water-surface } \\
\text { elevation } \\
\text { (ft, NAVD 88) }\end{array}$ & $\begin{array}{c}\text { Elevation } \\
\text { difference } \\
\text { (ft) }\end{array}$ \\
\hline 11.00 & 583.89 & 583.99 & 0.10 \\
12.00 & 584.89 & 584.97 & 0.08 \\
13.00 & 585.89 & 585.93 & 0.04 \\
14.00 & 586.89 & 586.94 & 0.05 \\
15.00 & 587.89 & 587.93 & 0.04 \\
\hline
\end{tabular}

$0.93 \mathrm{ft}$ at 17 locations and greater than 0.93 but less than 1.35 $\mathrm{ft}$ at 2 locations (table 5). Differences between measured and simulated water levels for models calibrated to high-water marks from the flood of January 10, 2008, on the Eel River in the study reach were less than $0.91 \mathrm{ft}$ at 10 locations and greater than 0.91 but less than $1.30 \mathrm{ft}$ at 3 locations (table 6).

Table 4. Comparison of water-surface elevations at U.S. Geological Survey streamgage 03328500, Eel River near Logansport, Indiana, with water-surface elevations output from the hydraulic model.

[ft, feet; NAVD 88, North American Vertical Datum of 1988]

\begin{tabular}{cccc}
\hline $\begin{array}{c}\text { Stage } \\
\text { (ft) }\end{array}$ & $\begin{array}{c}\text { Estimated } \\
\text { water-surface } \\
\text { elevation from } \\
\text { stage-discharge rating } \\
\text { (ft, NAVD 88) }\end{array}$ & $\begin{array}{c}\text { Modeled } \\
\text { water-surface } \\
\text { elevation } \\
\text { (ft, NAVD 88) }\end{array}$ & $\begin{array}{c}\text { Elevation } \\
\text { difference } \\
\text { (ft) }\end{array}$ \\
\hline 10.00 & 631.11 & 630.95 & -0.16 \\
11.00 & 632.11 & 632.10 & -0.01 \\
12.00 & 633.11 & 633.15 & 0.04 \\
13.00 & 634.11 & 634.12 & 0.01 \\
\hline
\end{tabular}

Table 5. Comparison of hydraulic-model output and surveyed high-water-mark elevations from the flood of July 7, 2003, for the Wabash River at Logansport, Indiana.

[ft, feet; NAVD 88, North American Vertical Datum of 1988]

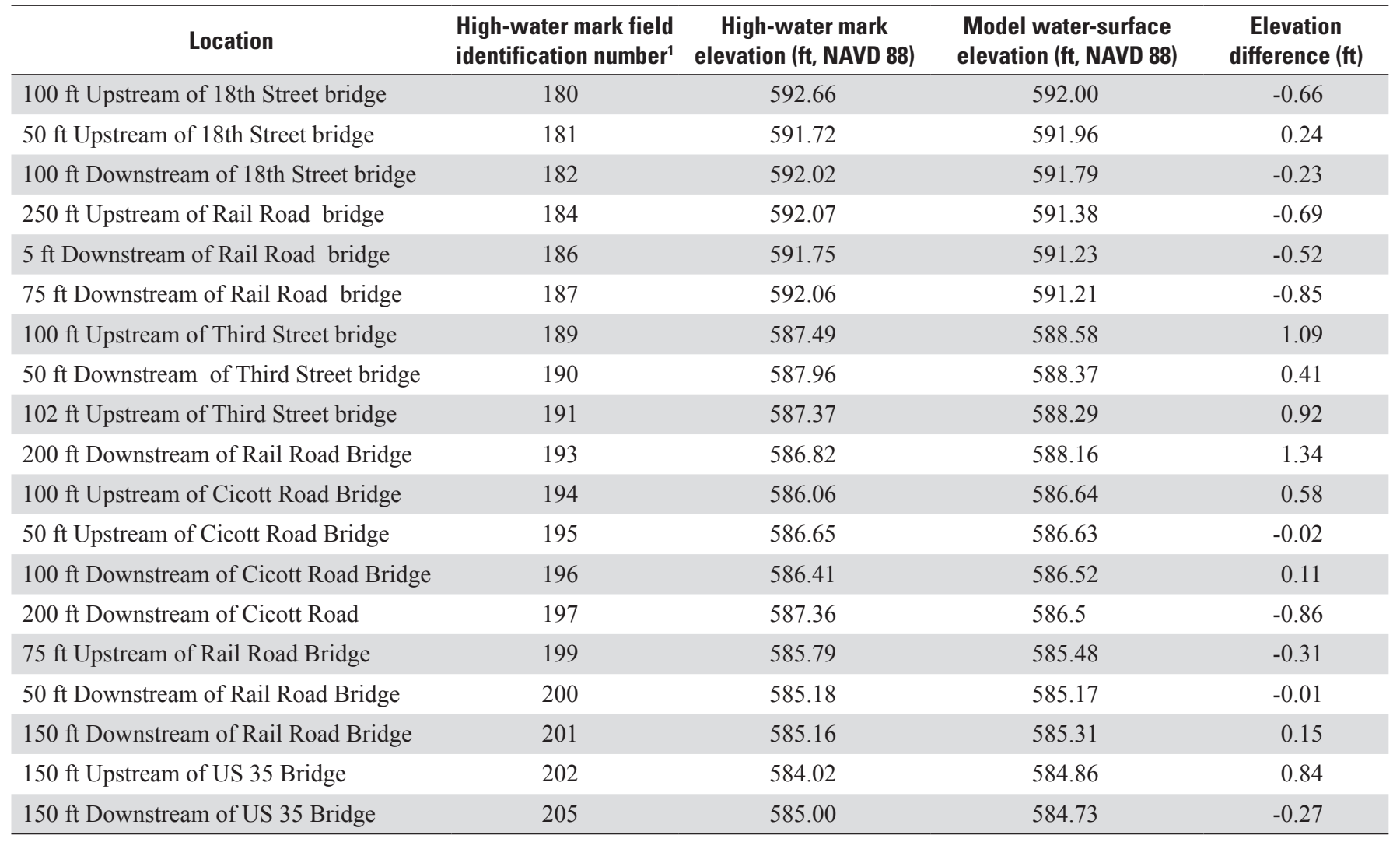

'Indiana Department of Natural Resources high-water marks for the flood of July 7, 2003, collected July 24, 2003. 
Table 6. Comparison of hydraulic-model output and surveyed high-water-mark elevations from the flood of January 10, 2008, for the Eel River near Logansport, Indiana.

[ft, feet; NAVD 88, North American Vertical Datum of 1988]

\begin{tabular}{|c|c|c|c|c|}
\hline Location & $\begin{array}{c}\text { High-water mark } \\
\text { field identification } \\
\text { number }{ }^{1}\end{array}$ & $\begin{array}{c}\text { High-water mark } \\
\text { elevation } \\
\text { (ft, NAVD 88) }\end{array}$ & $\begin{array}{c}\text { Model water-surface } \\
\text { elevation } \\
\text { (ft, NAVD 88) }\end{array}$ & $\begin{array}{l}\text { Elevation } \\
\text { difference } \\
\text { (ft) }\end{array}$ \\
\hline $250 \mathrm{ft}$ Upstream of County Road $450 \mathrm{~W}$ bridge & 21 & 623.48 & 623.98 & 0.50 \\
\hline $40 \mathrm{ft}$ Upstream of County Road $450 \mathrm{~W}$ bridge & 22 & 623.25 & 623.92 & 0.67 \\
\hline $60 \mathrm{ft}$ Downstream of County Road $450 \mathrm{~W}$ bridge & 23 & 623.27 & 623.82 & 0.55 \\
\hline $250 \mathrm{ft}$ Downstream of County Road $450 \mathrm{~W}$ bridge & 24 & 623.26 & 623.69 & 0.43 \\
\hline $125 \mathrm{ft}$ Upstream of County Road $200 \mathrm{E}$ bridge & 30 & 608.98 & 609.88 & 0.90 \\
\hline $250 \mathrm{ft}$ Downstream of County Road 200 E bridge & 32 & 608.42 & 609.71 & 1.29 \\
\hline Left Upstream corner of 6th Street bridge & 35 & 594.35 & 594.19 & -0.16 \\
\hline $40 \mathrm{ft}$ Downstream of 6th Street bridge & 36 & 593.45 & 593.58 & 0.13 \\
\hline $100 \mathrm{ft}$ Downstream of 6th Street bridge & 37 & 593.64 & 593.86 & 0.22 \\
\hline $225 \mathrm{ft}$ Upstream of 3rd Street bridge & 38 & 590.51 & 591.8 & 1.29 \\
\hline $350 \mathrm{ft}$ Downstream of 3rd Street bridge & 40 & 589.63 & 590.4 & 0.77 \\
\hline $400 \mathrm{ft}$ Downstream of $3 \mathrm{rd}$ Street bridge & 41 & 589.37 & 590.2 & 0.83 \\
\hline $850 \mathrm{ft}$ Upstream of Market Street Bridge & 43 & 587.17 & 588.3 & 1.13 \\
\hline
\end{tabular}

${ }^{1}$ Indiana Department of Natural Resources high-water marks for the flood of January 10, 2008, collected January 15,2008.

The comparisons of the high-water mark elevations to the modeled elevations are generally considered to be within the vertical accuracy of the model, especially because the floods occurred in different years and localized conditions such as $\log$ jams, ice flows, and backwater could have been in effect. The results demonstrate that the model is capable of simulating reasonable water levels over a wide range of flows in the basin. Details on techniques used in model development and calibration can be found in Bales and others (2007).

\section{Development of Water-Surface Profiles}

Profiles were developed for a total of 5 stages at $1-\mathrm{ft}$ intervals between $11 \mathrm{ft}$ and $15 \mathrm{ft}$ as referenced to USGS streamgage 03329000, Wabash River at Logansport, Ind. Discharges corresponding to the various stages were obtained from the most current stage-discharge relation (rating no. 38, June 17, 2012) at the Wabash River gage. The range of stages selected for the Wabash River cover the highest stages that have occurred since 1967. Before 1967, the river was not regulated by three upstream reservoirs and the flood stages were significantly higher than in recent years. Since this study is to document flooding for current conditions (regulated by reservoirs), stages over $15 \mathrm{ft}$ were not modeled. In the Wabash River model the values for the Eel River were estimated using the regression equation from a graph with the Wabash River peak discharges used as the explanatory variable and the Eel River peak discharges used as the dependent variable (fig. 3). The peak discharges used were from the period 1967 to 2011.

Discharges on the Wabash River upstream of the confluence with the Eel River for all profiles (table 7) were selected with the assumption that within the 5.7-mi reach there are no significant tributary or groundwater inflows. Downstream of the confluence, discharges were increased relative to the changes in the discharge of the Eel River.

Profiles for the Eel River were developed to represent flood peaks occurring on the same day as the Wabash River flood peaks. Concurrent annual peaks have occurred 12 times since 1967 (27 percent) and show the most serious flooding. Four profiles were developed at intervals ranging from $10 \mathrm{ft}$ to $13 \mathrm{ft}$ as referenced to USGS streamgage 03328500 , Eel River near Logansport, Ind. Discharges corresponding to the various stages were obtained from the most current stage-discharge relation (rating no. 23.0, January 9, 2003) at the Eel River gage. For the Eel River model the values for the Wabash River were predicted using the regression equation from a graph with the Eel River peak discharges used as the explanatory variable and the Wabash River peak discharges used as the dependent variable (fig. 4). The peak discharges used were from the period 1967 to 2011. 


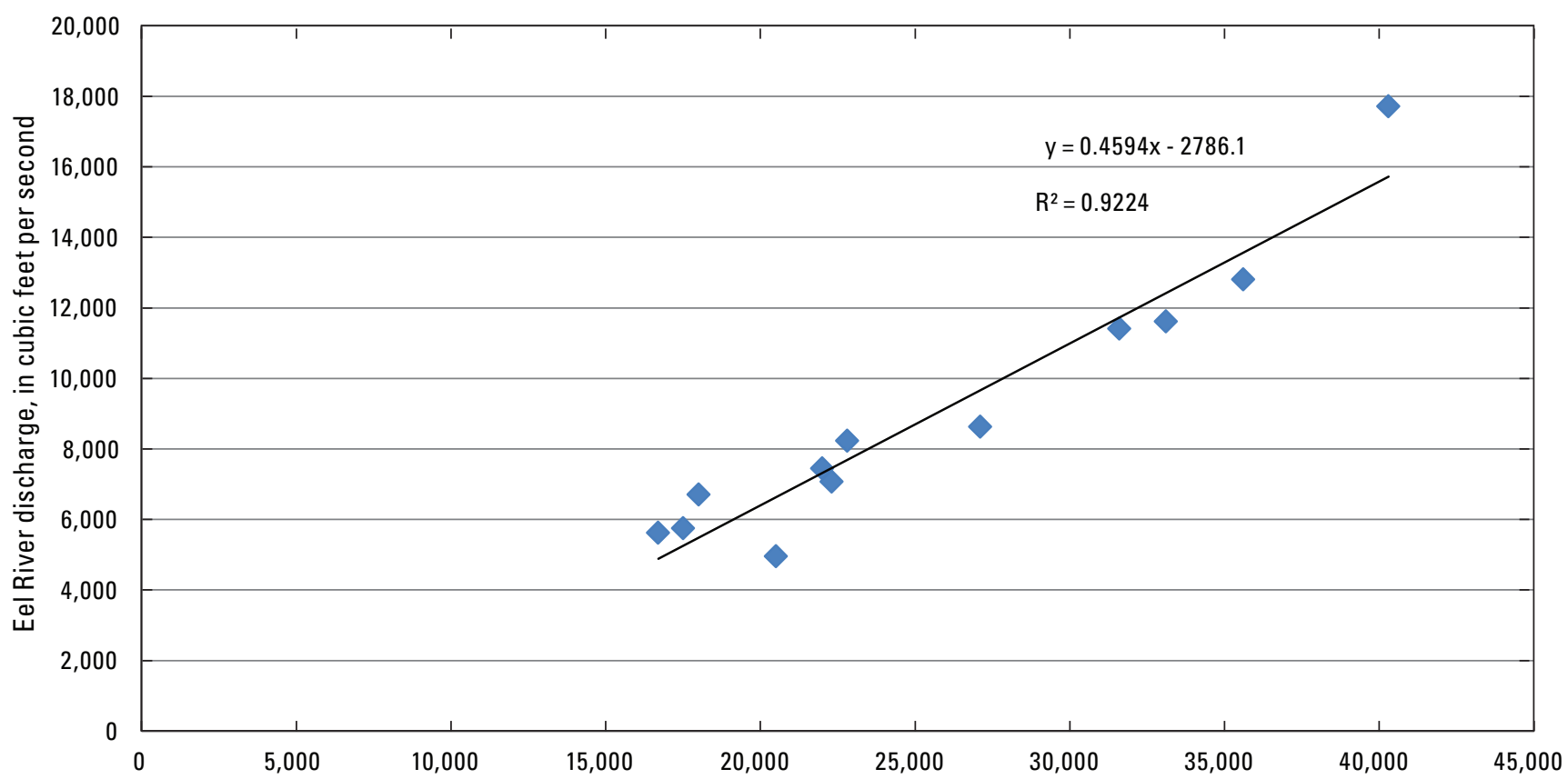

Wabash River discharge, in cubic feet per second

Figure 3. Regression plot and equation used to predict discharge at the Eel River.

Table 7. Stages, water-surface elevations, and corresponding discharge estimates for U.S. Geological Survey streamgages 03329000 , Wabash River at Logansport, and 03328500, Eel River near Logansport, Indiana, for simulated water-surface profiles.

[ $\left[\mathrm{ft}^{3} / \mathrm{s}\right.$, cubic feet per second; NAVD 88, North American Vertical Datum of 1988; sheet numbers correspond to the separate flood-inundation maps available online at http://pubs.usgs.gov/sim/2013/3293/]

\begin{tabular}{|c|c|c|c|c|c|}
\hline \multirow{2}{*}{ Location } & \multicolumn{5}{|c|}{ Sheet number } \\
\hline & 1 & 3 & 5 & 6 & 8 \\
\hline \multirow{3}{*}{$\begin{array}{l}\text { Streamgage } \\
\text { number } 03329000 \\
\text { Wabash River }\end{array}$} & \multicolumn{5}{|c|}{$\begin{array}{l}\text { Stage, in feet above gage datum (elevation, in feet above NAVD 88) } \\
\text { associated with the indicated discharge value (rating 38) }\end{array}$} \\
\hline & $\begin{array}{c}11.0 \\
(583.89)\end{array}$ & $\begin{array}{c}12.0 \\
(584.89)\end{array}$ & $\begin{array}{c}13.0 \\
(585.89)\end{array}$ & $\begin{array}{c}14.0 \\
(586.89)\end{array}$ & $\begin{array}{c}15.0 \\
(587.89)\end{array}$ \\
\hline & \multicolumn{5}{|c|}{ Discharge $\left(\mathrm{ft}^{3} / \mathrm{s}\right)$} \\
\hline \multirow{2}{*}{ Location } & \multicolumn{5}{|c|}{ Sheet number } \\
\hline & 2 & 4 & 7 & 9 & \\
\hline \multirow{2}{*}{$\begin{array}{l}\text { Streamgage } \\
\text { number } 03328500 \\
\text { Eel River }\end{array}$} & \multicolumn{5}{|c|}{$\begin{array}{l}\text { Stage, in feet above gage datum (elevation, in feet above NAVD 88) } \\
\text { associated with the indicated discharge value (rating } 23 \text { ) }\end{array}$} \\
\hline & 9,935 & 12,570 & 15,530 & 18,800 & \\
\hline
\end{tabular}




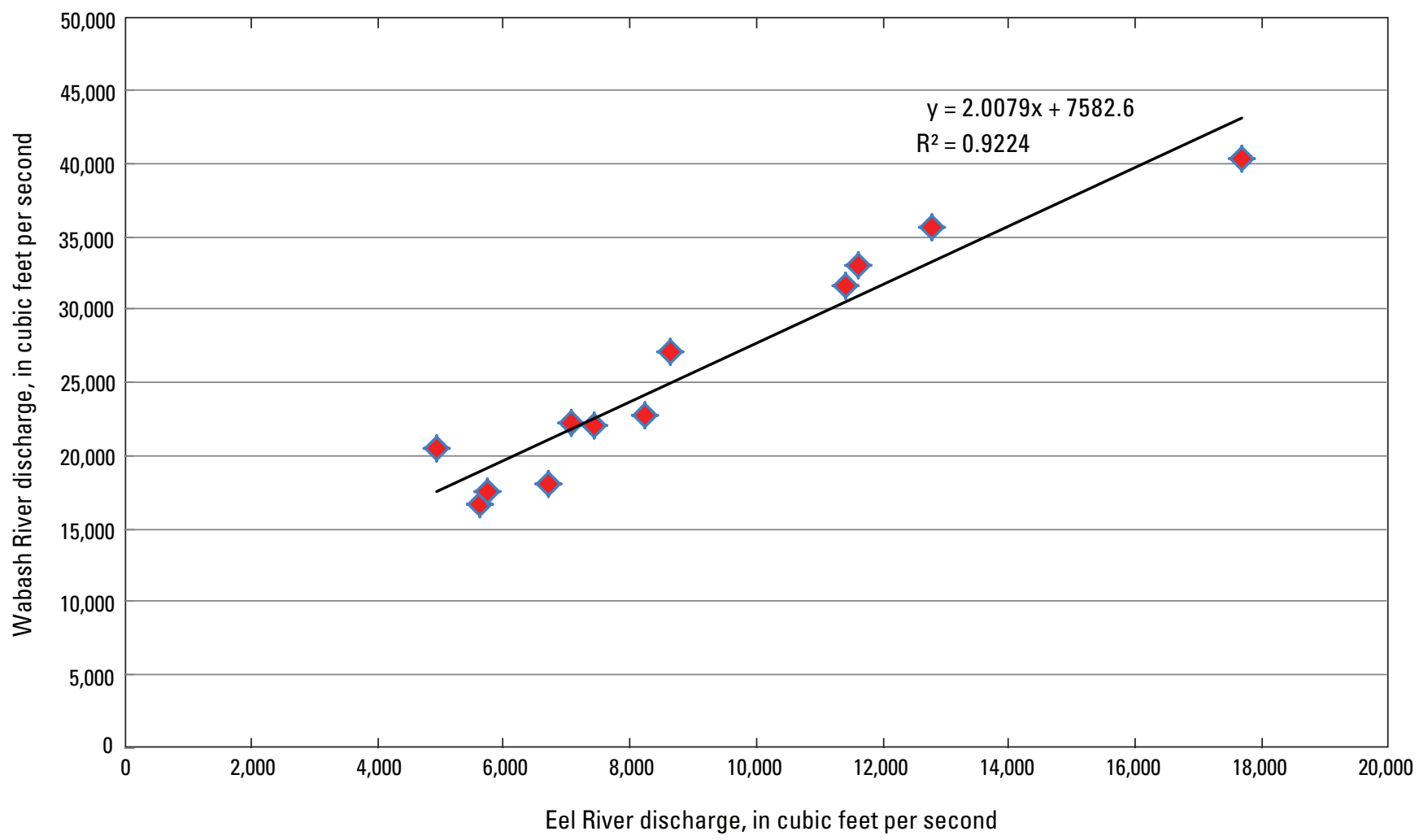

Figure 4. Regression plot and equation used to predict discharge at the Wabash River.

Discharges at locations downstream of the Eel River gage and upstream of the Wabash River gage were determined by calculating cubic feet per second per square mile $\left.\left[\left(\mathrm{ft}^{3} / \mathrm{s}\right) / \mathrm{mi}^{2}\right)\right]$. The $\left(\mathrm{ft}^{3} / \mathrm{s}\right) / \mathrm{mi}^{2}$ is defined as the average number of cubic feet of water per second flowing from each square mile of area drained by a stream, assuming that the runoff is distributed uniformly in time and area. First, runoff values were calculated for the two USGS streamgages (03329000 or 03328500), and, second, the corresponding runoff value was multiplied by the drainage area at a specified downstream or upstream location. Drainage areas were determined using U.S. Geological Survey, StreamStats (U.S. Geological Survey, 2012).

\section{Inundation Mapping}

Flood-inundation maps were created for a reach of the Wabash River at Logansport and a reach of the Eel River near Logansport, Ind. The maps were created in a GIS by combining the water-surface profiles and DEM data. The DEM data were derived from $3.9 \mathrm{ft}$ horizontal resolution lidar data with a vertical accuracy of $0.37 \mathrm{ft}$ obtained from Aero-Metric, Inc., Sheboygan, Wis. Estimated flood-inundation boundaries for each simulated profile were developed with HEC-GeoRAS software (U.S. Army Corps of Engineers, 2009). HEC-GeoRAS is a set of procedures, tools, and utilities for processing geospatial data in ArcGIS using a graphical user interface. The interface allows the preparation of geometric data for import into HEC-RAS and processes simulation results exported from HEC-RAS (U.S. Army Corps of Engineers, 2010). USGS personnel then modified the HEC-GeoRAS results to ensure a hydraulically reasonable transition of the boundary between modeled cross sections relative to the contour data for the land surface (Whitehead and Ostheimer, 2009).

The resulting inundation maps have a vertical accuracy of about plus or minus $1.0 \mathrm{ft}$. The maps show estimated floodinundated areas overlaid on high-resolution, georeferenced aerial photographs of the study area for each of the watersurface profiles that were generated by the hydraulic model (sheets 1-9).

\section{Wabash and Eel Rivers at Logansport, Indiana, Flood-Inundation Maps on the Internet}

The flood-inundation maps and current study documentation are available online at the USGS Publications Warehouse (http://pubs.usgs.gov/sim/3293). Also, a Flood Inundation Mapping Science Web site has been established 
at $h$ ttp://water.usgs.gov/osw/flood inundation/ to provide a portal for USGS flood-inundation study information to the public. That Web portal has a link (http://wim.usgs.gov/FIMI/ FloodInundationMapper.html) to interactive online map libraries that can be downloaded in several commonly used electronic file formats. At the map library site, each stream reach displayed contains further links to NWISWeb graphs of the current stage and streamflow at USGS streamgages 03329000 and 03328500 to which the inundation maps are referenced. A link also is provided to the NWS AHPS site (http:/water. weather.gov/ahps/), so that the user can obtain applicable information on forecasted peak stage. The estimated floodinundation maps are displayed in sufficient detail to note the extent of flooding with respect to individual structures so that preparations for flooding and decisions for emergency response can be performed efficiently. Buildings that are shaded do not reflect inundation but denote that bare-earth surfaces in the vicinity of the buildings are inundated. When the water depth (as indicated in the Web mapping application by holding the cursor over an inundated area) in the vicinity of the building of interest exceeds that building's height, the structure can be considered fully submerged.

\section{Disclaimer for Flood-Inundation Maps}

Inundated areas shown should not be used for navigation, regulatory, permitting, or other legal purposes. The USGS provides these maps "as-is" for a quick reference, emergency planning tool but assumes no legal liability or responsibility resulting from the use of this information.

\section{Uncertainties and Limitations Regarding Use of Flood-Inundation Maps}

Although the flood-inundation maps represent the boundaries of inundated areas with a distinct line, some uncertainty is associated with these maps. The flood boundaries shown were estimated based on water stages (water-surface elevations) and streamflows at USGS streamgages 03329000 and 03328500. Water-surface elevations along the stream reaches were estimated by steady-state hydraulic modeling, assuming unobstructed flow, and using discharges and hydrologic conditions anticipated at the USGS streamgages. The hydraulic model reflects the land-cover characteristics and any bridge, dam, levee, or other hydraulic structures existing as of August 2012. Unique meteorological factors (timing and distribution of precipitation) may cause actual discharges along the modeled reach to vary from those assumed during a flood and lead to deviations in the water-surface elevations and inundation boundaries shown. Additional areas may be flooded due to unanticipated conditions such as changes in the streambed elevation or roughness, backwater into tributaries along a main stem river, or backwater from localized debris or ice jams. The accuracy of the floodwater extent portrayed on these maps will vary with the accuracy of the DEM used to simulate the land surface. Additional uncertainties and limitations pertinent to this study are described elsewhere in this report.

If this series of flood-inundation maps will be used in conjunction with NWS river forecasts, the user should be aware of additional uncertainties that may be inherent or factored into NWS forecast procedures. The NWS uses forecast models to estimate the quantity and timing of water flowing through selected stream reaches in the United States. These forecast models (1) estimate the amount of runoff generated by precipitation and snowmelt, (2) simulate the movement of floodwater as it proceeds downstream, and (3) predict the flow and stage (and water-surface elevation) for the stream at a given location (AHPS forecast point) throughout the forecast period (every 6 hours and 3 to 5 days out in many locations). For more information on AHPS forecasts, please see http:// water.weather.gov/ahps/pcpn_and_river_forecasting.pdf.

\section{Summary}

A series of estimated flood-inundation maps was developed in cooperation with the Indiana Office of Community and Rural Affairs for the Wabash and the Eel Rivers at Logansport, Ind. These maps, in conjunction with the real-time stage data from the USGS streamgages at Wabash River at Logansport (sta. no. 03329000) and Eel River near Logansport (sta. no. 03328500) and National Weather Service flood-stage forecasts, will help to guide the general public in taking individual safety precautions and will provide city officials with a tool to efficiently manage emergency flood operations and flood mitigation efforts.

The maps were developed by using the U.S. Army Corps of Engineers' HEC-RAS and HEC-GeoRAS programs to compute water-surface profiles and to delineate estimated flood-inundation areas for selected stream stages. The maps show estimated (shaded) flood-inundation areas overlaid on high-resolution, georeferenced aerial photographs of the study area for stream stages between $11 \mathrm{ft}$ and $15 \mathrm{ft}$ at the Wabash River streamgage and $10 \mathrm{ft}$ to $13 \mathrm{ft}$ on the Eel River streamgage. The maps are available at a USGS Web portal at http://pubs.usgs.gov/sim/3293/. Interactive use of the maps by using the mouse cursor to click within the shaded areas can give users a general indication of depth of water at any point. 


\section{References Cited}

Aero-Metric, Inc., 2010, Indiana Flood LiDAR (ARRA) Task order, remote-sensing image: Sheboygan, Wis., Aero-Metric, Inc.

Arcement, G.J., and Schneider, V.R., 1989, Guide for selecting Manning's roughness coefficients for natural channels and flood plains: U.S. Geological Survey Water-Supply Paper $2339,38 \mathrm{p}$.

Bales, J.D., Wagner, C.R., Tighe, K.C., and Terziotti, Silvia, 2007, LiDAR-derived flood-inundation maps for realtime flood-mapping applications, Tar River Basin, North Carolina: U.S. Geological Survey Scientific Investigations Report 2007-5032, 42 p.

Federal Emergency Management Agency (FEMA), 1979, Flood insurance study for Cass County, Indiana: Washington, D.C., Flood Insurance Study Number 188017CV000A, $14 \mathrm{p}$.

Gray, H.H., 2000, Physiographic divisions of Indiana: Bloomington, Indiana Geological Survey Special Report 61, $15 \mathrm{p} ., 1 \mathrm{pl}$.
U.S. Army Corps of Engineers, Hydrologic Engineering Center, 2009, HEC-GeoRAS, GIS tools for support of HECRAS using ArcGIS-User's manual, version 4.2 [variously paged].

U.S. Army Corps of Engineers, Hydrologic Engineering Center, 2010, HEC-RAS River Analysis System-Hydraulic reference manual, version 4.1 [variously paged].

U.S. Census Bureau, 2010, 2010 Census interactive population search IN- Logansport city: Washington, D.C., available at http://www.census.gov/2010census/popmap/ipmtext. php? $f=18$.

U.S. Geological Survey, 2012, StreamStats for Indiana streams: accessed November 2012 at $h t t p: / / s t r e a m s t a t s$. usgs.gov/indiana.html.

Whitehead, M.T., and Ostheimer, C.J., 2009, Development of a flood-warning system and flood-inundation mapping for the Blanchard River in Findlay, Ohio: U.S. Geological Survey Scientific Investigations Report 2008-5234, 9 p. 



\section{$\frac{\mathbb{3}}{\mathrm{C}}$}

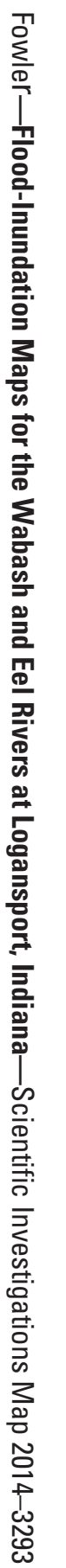

